\title{
The professional attitudes of teachers of physical education
}

\author{
RADOSŁAW MUSZKIETA ${ }^{1}$, MAREK NAPIERAŁA ${ }^{2}$, MIROSŁAWA CIEŚLICKA ${ }^{2}$, WALERY ZUKOW ${ }^{1}$, \\ ZHANETA KOZINA ${ }^{3}$, SERGII IERMAKOV ${ }^{3}$, MIROSŁAW GÓRNY ${ }^{4}$ \\ ${ }^{1}$ Faculty of Earth Sciences, Nicolaus Copernicus University, Torun, POLAND \\ ${ }^{2}$ Department of Human Physiology Nicolaus Copernicus University, Collegium Medicum, Bydgoszcz, \\ POLAND \\ 3Department of Tourism and Recreation, Gdansk University of Physical Education and Sport, Gdansk, \\ POLAND \\ ${ }^{4}$ Faculty of Physical Education and Sport, University of Physical Education, Poznań, POLAND
}

Published online: January 31, 2019

(Accepted for publication December 03, 2018)

DOI:10.7752/jpes.2019.s1014

\begin{abstract}
Introduction Educational systems are going through in many countries of the world, including in Poland, the crisis. Reforms to the educational systems, giving them a new shape and image, with revised objectives and tasks. Aim. Was the aim of work qualification of the professional teachers' attitudes the physical education, which have on quality the direct and indirect influence the education and the children and youth's education. Material and method. It investigations were subjected was the teachers of physical education (woman $-\mathrm{N}=$ 282 ; men $-\mathrm{N}=298$ ) with professional full qualifications working at elementary schools, secondary-school and secondary in Poznań $(\mathrm{N}=204)$, Wrocław $(\mathrm{N}=171)$ and Łódź $(\mathrm{N}=205)$. It totality was has given an examination was 580 teachers. The investigations were polled with the help of the relating the attitudes of professional teachers of physical education questionnaire. Results. In result of conducted analysis of results of investigations affirm, that the studied teachers' decided majority, first of all the women be characterized desirable and the positive professional attitudes, social and educational. Conclusions. The attitude of professional teachers of physical education can be considered satisfactory, and hence giving the chance for a better quality of education and upbringing of children and young people. However, there is a dissonance between declared attitudes and the actual proceedings for many teachers.
\end{abstract}

Key words: attitude, physical education teacher, educational process.

\section{Introduction}

Educational systems are going through in many countries of the world, including in Poland, the crisis. Reforms to the educational systems, giving them a new shape and image, with revised objectives and tasks.

It can be assumed that the most beautiful assumptions of education reform can be effectively implemented only by competent teachers, aware of the important goals and tasks that they face. Teachers' professional attitudes are and will be a key factor in future educational effects.

A good teacher can not be anyone, and the mastery in didactic and educational work is achieved by people with specific personality traits (Dindorf 1995). Nowadays, it seems extremely important to find the ideal teacher model - a teacher of a new era, a future teacher, one who should meet new educational challenges. Thus, probably what we call the pedagogical "talent", which consists in the intuitive selection of pedagogical measures appropriate in a given situation, is mainly determined by the teacher's mastery (Brophy 1984).

Research on management class has shown that it is not possible to distinguish good teachers from the bad on the basis of how they respond to disciplinary problems or breaking the rules in force in the classroom.

The difference between such teachers is primarily visible when you observe the ways they use to prevent such problems from occurring. One of the characteristic features of teachers who are able to prevent such problems and are able to create and maintain effective learning conditions in class, has been defined as "being with" or the ability to closely observe what is happening in the classroom, and to show students, that he or she is "with this" (Brophy 1984).

Thus, "being with" is a component of effective class management that leads to the conditions for effective learning - on this basis, we can therefore conclude that teachers should be prepared to "be with" (Pearson 1994).

The development of his personal qualities that are essential in communicating with students is of great importance in the process of educating a physical education teacher (Özkara et al., 2017, Leifa, Zheleznyak, 2017). 


\section{RADOSŁAW MUSZKIETA, MAREK NAPIERAŁA, MIROSŁAWA CIEŚLICKA, WALERY ZUKOW, ZHANETA KOZINA, SERGII IERMAKOV, MIROSŁAW GÓRNY}

The teacher must be able to take into account didactic models of building the educational process (Hasan, Melki, 2017) and the psychological peculiarities of constructing and teaching movement activities (Nowak, 2016).

Konarzewski (1998) diagnosing the role of teachers stated that the teacher is a noble profession: it is a pity that the majority of teachers do not grow up with him.

Czabański (1997) drew attention to the importance of every teacher in his soul at work. He stated that often the teacher, unwittingly, without special intentions, wanted the pupil to become similar to him, that he would fulfill his unfulfilled desires and ideas. He was similar to him, but more perfect, deprived of his imperfections, imperfections and richer about his experiences.

That is why in no other profession depends on what man is.

Objective of the work

The aim of the work was to determine the professional attitudes of physical education teachers, which have a direct and indirect impact on the quality of education and upbringing of children and youth.

\section{Material and test method}

The research involved 580 physical education teachers (282 women and 298 men) with full vocational qualifications, working in primary, junior high and secondary schools in Poznań $(\mathrm{N}=204)$, Łódź $(\mathrm{N}=205)$ and Wrocław $(\mathrm{N}=171)$.

Using the questionnaire consisting of 50 problem questions, an attempt was made to determine the attitudes and professional competences of physical education teachers. This study discusses 9 research problems.

Statistical analysis. The data were analyzed using the statistical program Statistica 13.0 PL (StatSoft, Poland). The value of the analyzed parameters measured is shown using the value of the mean and standard deviation, and for non-measurable using counts and percentage. The data were subjected to statistical analysis using the independence test Chi square. The strength of the relationship between the test variable was calculated using Cramer's coefficient. Analysis was carried out by significance level p $<0.05$ (probability 95\%).

\section{Analysis of test results}

$32.1 \%$ of the respondents like their physical education teacher profession, including $34.4 \%$ of women and $29.9 \%$ of men. Women - physical education teachers from Wrocław, Łódź and Poznań - are more determined in emotional expression to their profession than men from these cities.

We found that $57 \%$ of teachers in primary schools $(59.7 \%$ of women, $54.6 \%$ of men $), 54.7 \%(57 \%$ women, $52.5 \%$ men) from junior high and 50.2\% (35.4\%) women, 64\% of men) from post-primary schools enjoys learning and practicing the profession of physical education teacher. Every tenth respondent $(7.8 \%$ women, $12.1 \%$ men) can not determine the degree of passion for the teaching profession. Unfortunately, $2.3 \%$ of teachers from Wrocław, 2.9\% from Łódź and 3.9\% from Poznań do not like, and 1.8\% of teachers from Lodz do not like their profession.

Teachers with negative attitude to the learned and practiced physical education teacher constitute a minimal percentage of all respondents, but it is a group that occurs in educational practice (Table 1). Table 1. The problem, "I like your teaching profession PE"

\begin{tabular}{|c|c|c|c|c|c|c|c|}
\hline \multirow{2}{*}{$\begin{array}{l}\text { Type of } \\
\text { school }\end{array}$} & \multirow[b]{2}{*}{ Sex } & \multirow[b]{2}{*}{$N$} & \multicolumn{5}{|c|}{ Answers } \\
\hline & & & Definitely yes & Yes & $\begin{array}{c}\mathrm{I} \text { am } \\
\text { determined to }\end{array}$ & No & Definitely not \\
\hline \multirow{2}{*}{ SP } & $\mathrm{K}$ & 124 & 27.4 & 59.7 & 8.1 & 4.8 & 0 \\
\hline & $\mathrm{M}$ & 132 & 31.8 & 54.6 & 12.1 & 1.5 & 0 \\
\hline \multirow{2}{*}{ G } & $\mathrm{K}$ & 79 & 38.0 & 57.0 & 2.5 & 0 & 2.5 \\
\hline & $M$ & 80 & 30.0 & 52.5 & 17.5 & 0 & 0 \\
\hline \multirow{2}{*}{ SPP } & $\mathrm{K}$ & 79 & 41.8 & 35.4 & 12.7 & 10.1 & 0 \\
\hline & $\mathrm{M}$ & 86 & 26.7 & 64.0 & 7.0 & 2.3 & 0 \\
\hline & & & \multicolumn{5}{|c|}{$\square^{2}=56.277 * *$} \\
\hline \multirow{2}{*}{ Together } & K & 282 & 34.4 & 52.1 & 7.8 & 5.0 & 0.7 \\
\hline & $\mathrm{M}$ & 298 & 29.9 & 56.7 & 12.1 & 1.3 & 0 \\
\hline & & & \multicolumn{5}{|c|}{$\square^{2}=12.379 *$} \\
\hline Together & $\mathrm{M}+\mathrm{M}$ & 580 & 32.1 & 54.5 & 10.0 & 3.1 & 0.3 \\
\hline
\end{tabular}

Explanations (refer to all of the attached tables): SP - primary school, G - high school, SPP - secondary school $\mathrm{K}$ - women, $\mathrm{M}-$ male, * Significance level $\mathrm{p}<0.05$ level of significance ** $\mathrm{p}<0.01$

The prevailing percentage of physical education teachers surveyed from Wrocław, Łódź and Poznań (89.3\%) declared that the child is the most important subject of work and life at school (definitely yes - 31.7\%, yes $57.6 \%)$. The most undecided teachers were represented by junior high schools $(16.4 \%$ of all respondents, including $12.7 \%$ of women and $20 \%$ of men), to a lesser extent primary schools ( $7 \%$ of the total, including $8.1 \%$ of women and $6.1 \%$ of men ) and above-basic (2.4\% of the total, including $0 \%$ of women and $4.7 \%$ of men). $2.9 \%$ of teachers from Poznań, 2.3\% from Wrocław and 2\% from Łódź stated that the child is not the most important subject of work and life at school and decided that they do not like all children and young people 


\section{RADOSŁAW MUSZKIETA, MAREK NAPIERAŁA, MIROSŁAWA CIEŚLICKA, WALERY ZUKOW, ZHANETA KOZINA, SERGII IERMAKOV, MIROSŁAW GÓRNY}

(Table 2). Table 2. The problem, "I like all children and young people. The child is the most important subject of work and school life "

\begin{tabular}{|c|c|c|c|c|c|c|c|}
\hline \multirow{2}{*}{$\begin{array}{l}\text { Type of } \\
\text { school }\end{array}$} & \multirow[b]{2}{*}{ Sex } & \multirow[b]{2}{*}{$N$} & \multicolumn{5}{|c|}{ Answers } \\
\hline & & & Definitely yes & Yes & $\begin{array}{c}\mathrm{I} \text { am } \\
\text { determined to }\end{array}$ & No & Definitely not \\
\hline \multirow{2}{*}{ SP } & $\mathrm{K}$ & 124 & 35.5 & 53.2 & 8.1 & 3.2 & 0 \\
\hline & $\mathrm{M}$ & 132 & 36.4 & 57.6 & 6.1 & 0 & 0 \\
\hline \multirow{2}{*}{ G } & $\mathrm{K}$ & 79 & 39.2 & 48.1 & 12.7 & 0 & 0 \\
\hline & $\mathrm{M}$ & 80 & 25.0 & 50.0 & 20.0 & 5.0 & 0 \\
\hline \multirow{2}{*}{ SPP } & $\mathrm{K}$ & 79 & 29.1 & 65.8 & 0 & 5.1 & 0 \\
\hline & $\mathrm{M}$ & 86 & 20.9 & 72.1 & 4.7 & 2.3 & 0 \\
\hline & & & \multicolumn{5}{|c|}{$\square^{2}=47.602 * *$} \\
\hline \multirow{2}{*}{ Together } & $\mathrm{K}$ & 282 & 34.8 & 55.3 & 7.1 & 2.8 & 0 \\
\hline & $\mathrm{M}$ & 298 & 28.9 & 59.7 & 9.4 & 2.0 & 0 \\
\hline & & & \multicolumn{5}{|c|}{$\square^{2}=3,412$} \\
\hline Together & $M+M$ & 580 & 31.7 & 57.6 & 8.3 & 2.4 & 0 \\
\hline
\end{tabular}

In 2000, the professional promotion of teachers was introduced by the Minister of National Education. In the same year, I conducted research among physical education teachers representing various types of schools from three places. Analyzing the results of research, I observed that $77 \%$ of teachers $(82.9 \%$ from Lodz, $75.4 \%$ from Wrocław, 72.6\% from Poznań) do not consider getting professional promotion degrees for a waste of time. Teachers from junior high schools more often expressed such opinion (not $-63.5 \%$, definitely not $-17.6 \%$ ) than from secondary schools (not $-59.4 \%$, definitely not $-21.2 \%$ ) and primary (no $-53,5 \%$, definitely not $-18.8 \%$ ). For $5.9 \%$ (definitely yes - 2\% teachers from Poznań, yes $-5.2 \%$ of the total number of teachers) of physical education teachers surveyed, gaining next levels of professional promotion turned out to be a waste of time. Every fourth teacher surveyed and every seventh teacher $(17.1 \%$ of the total) did not have a specific opinion on career advancement (Table 3 ).

Table 3. The problem of "Gaining a professional promotion I think it is a waste of time"

\begin{tabular}{|c|c|c|c|c|c|c|c|}
\hline \multirow{2}{*}{$\begin{array}{l}\text { Type of } \\
\text { school }\end{array}$} & \multirow[b]{2}{*}{ Sex } & \multirow[b]{2}{*}{$N$} & \multicolumn{5}{|c|}{ Answers } \\
\hline & & & Definitely yes & Yes & $\begin{array}{c}\mathrm{I} \text { am } \\
\text { determined to }\end{array}$ & No & Definitely not \\
\hline \multirow{2}{*}{ SP } & $\mathrm{K}$ & 124 & 0 & 4.8 & 25.0 & 55.7 & 14.5 \\
\hline & $\mathrm{M}$ & 132 & 1.5 & 4.6 & 19.7 & 51.5 & 22.7 \\
\hline \multirow{2}{*}{$\mathrm{G}$} & $\mathrm{K}$ & 79 & 0 & 2.5 & 20.3 & 57.0 & 20.2 \\
\hline & $\mathrm{M}$ & 80 & 0 & 2.5 & 12.5 & 70.0 & 15.0 \\
\hline \multirow{2}{*}{ SPP } & $\mathrm{K}$ & 79 & 0 & 7.6 & 12.7 & 55.7 & 24.1 \\
\hline & $\mathrm{M}$ & 86 & 2.3 & 9.3 & 7.0 & 62.8 & 18.6 \\
\hline & & & \multicolumn{5}{|c|}{$\square^{2}=33.292 *$} \\
\hline \multirow{2}{*}{ Together } & $\mathrm{K}$ & 282 & 0 & 5.0 & 20.2 & 56.0 & 18.8 \\
\hline & $\mathrm{M}$ & 298 & 1.3 & 5.4 & 14.1 & 59.7 & 19.5 \\
\hline & & & \multicolumn{5}{|c|}{$\square^{2}=7.386$} \\
\hline Together & $M+M$ & 580 & 0.7 & 5.2 & 17.1 & 57.9 & 19.1 \\
\hline
\end{tabular}

The vast majority of the teachers surveyed are aware that the effectiveness of the physical education teacher's activity requires permanent improvement and further education (Wrocław: definitely yes - 42.1\%, yes $48.5 \%$; Łódź: definitely yes - 36.1\%, yes - $59 \%$ Poznań: definitely yes $-22.1 \%$, yes - 68.2\%). Almost $6 \%(7.1 \%$ women, $4.7 \%$ men) of the surveyed teachers did not express their opinion on the importance of improving the knowledge and teaching skills. 2.3\% of teachers from Wrocław and 3.9\% from Poznan disagreed with the thesis put forward. To sum up the problem analysis, the attitudes of teachers in the area of understanding the relationships between work efficiency and improvement and training are very satisfactory (Table 4).

Table 4. Problem "Effective functioning as a teacher of physical education require continuous improvement and training"

\begin{tabular}{|c|c|c|c|c|c|c|c|}
\hline \multirow{2}{*}{$\begin{array}{l}\text { Type of } \\
\text { school }\end{array}$} & \multirow[b]{2}{*}{ Sex } & \multirow[b]{2}{*}{$N$} & \multicolumn{5}{|c|}{ Answers } \\
\hline & & & Definitely yes & Yes & $\begin{array}{c}\mathrm{I} \text { am } \\
\text { determined to }\end{array}$ & No & Definitely not \\
\hline \multirow{2}{*}{ SP } & $\mathrm{K}$ & 124 & 29.8 & 60.5 & 6.5 & 3.2 & 0 \\
\hline & $\mathrm{M}$ & 132 & 25.8 & 68.2 & 4.6 & 1.5 & 0 \\
\hline \multirow{2}{*}{$\mathrm{G}$} & $\mathrm{K}$ & 79 & 45.6 & 46.8 & 7.6 & 0 & 0 \\
\hline & $\mathrm{M}$ & 80 & 35.0 & 57.5 & 7.5 & 0 & 0 \\
\hline \multirow{2}{*}{ SPP } & $\mathrm{K}$ & 79 & 31.7 & 55.7 & 7.6 & 0 & 5.1 \\
\hline & $\mathrm{M}$ & 86 & 36.1 & 59.3 & 2.3 & 0 & 2.3 \\
\hline & & & \multicolumn{5}{|c|}{$\square^{2}=41.683 * *$} \\
\hline \multirow{2}{*}{ Together } & $\mathrm{K}$ & 282 & 34.8 & 55.3 & 7.1 & 1.4 & 1.4 \\
\hline & $\mathrm{M}$ & 298 & 31.2 & 62.8 & 4.7 & 0.7 & 0.7 \\
\hline & & & \multicolumn{5}{|c|}{$\square^{2}=4.887$} \\
\hline Together & $M+M$ & 580 & 32.9 & 59.1 & 5.9 & 1.0 & 1.0 \\
\hline
\end{tabular}




\section{RADOSŁAW MUSZKIETA, MAREK NAPIERAŁA, MIROSŁAWA CIEŚLICKA, WALERY ZUKOW, ZHANETA KOZINA, SERGII IERMAKOV, MIROSŁAW GÓRNY}

As can be seen from the data in Table 5, the majority of teachers surveyed (women: no - 51.1\%, definitely not $-25.5 \%$, men: no - 54\%, definitely not - $16.1 \%$ ) disagreed with the thesis that "positive attitude of students towards physical culture does not enjoy teachers as much as their sports results". Unfortunately, as much as $26.9 \%$ of teachers from Poznań (definitely yes - 8.8\%, yes - 18.1\%), slightly less from Łódź (16.6\%, definitely yes $-4.9 \%$, yes $-11.7 \% \%$ ) and Wrocław (14\%, definitely yes $-3.5 \%$, yes $-10.5 \%)$ think that their sports results are more enjoyable than their positive attitude towards physical culture. This attitude of physical education teachers has its significant reflection in the system of assessing students' achievements. It was also found, analyzing the research results, that $5 \%$ of women and $9.4 \%$ of men did not comment on the above topic (Table 5).

Table 5. The problem of "students' positive attitude towards physical culture does not enjoy me as much as their athletic performance"

\begin{tabular}{|c|c|c|c|c|c|c|c|}
\hline \multirow{2}{*}{$\begin{array}{l}\text { Type of } \\
\text { school }\end{array}$} & \multirow[b]{2}{*}{ Sex } & \multirow[b]{2}{*}{$N$} & \multicolumn{5}{|c|}{ Answers } \\
\hline & & & Definitely yes & Yes & $\begin{array}{c}\mathrm{I} \text { am } \\
\text { determined to }\end{array}$ & No & Definitely not \\
\hline \multirow{2}{*}{ SP } & $\mathrm{K}$ & 124 & 9.7 & 14.5 & 8.1 & 44.4 & 23.4 \\
\hline & $\mathrm{M}$ & 132 & 4.6 & 16.7 & 9.1 & 54.6 & 15.2 \\
\hline \multirow{2}{*}{ G } & $\mathrm{K}$ & 79 & 7.6 & 7.6 & 5.1 & 49.4 & 30.4 \\
\hline & $\mathrm{M}$ & 80 & 10.0 & 15.0 & 15.0 & 47.5 & 12.5 \\
\hline \multirow{2}{*}{ SPP } & $\mathrm{K}$ & 79 & 0 & 12.7 & 0 & 63.3 & 24.1 \\
\hline & $\mathrm{M}$ & 86 & 2.3 & 12.8 & 4.7 & 59.3 & 20.9 \\
\hline & & & \multicolumn{5}{|c|}{$\square^{2}=44.097 * *$} \\
\hline \multirow{2}{*}{ Together } & $\mathrm{K}$ & 282 & 6.4 & 12.1 & 5.0 & 51.1 & 25.5 \\
\hline & $\mathrm{M}$ & 298 & 5.4 & 15.1 & 9.4 & 54.0 & 16.1 \\
\hline & & & \multicolumn{5}{|c|}{$\square^{2}=11.631 *$} \\
\hline Together & $M+M$ & 580 & 5.9 & 13.6 & 7.2 & 52.6 & 20.7 \\
\hline
\end{tabular}

Positive professional attitudes in terms of taking into account real interests and needs of students in the implementation of physical education classes were characterized by $93 \%$ (definitely yes - $28.1 \%$ women and $22 \%$ men, yes $-67.4 \%$ women and $68.3 \%$ men) of the teachers Wrocław, $87.3 \%$ of Łódź (definitely yes - $22 \%$ of women and $10.4 \%$ of men, yes $-63.3 \%$ of women and $79.2 \%$ of men) and $85.3 \%$ of Poznań (definitely yes $21.4 \%$ of women and $10 \%$ men, yes $-73.8 \%$ women and $68.3 \%$ men). The lack of determination in choosing the affirmative answer was found in $7.1 \%$ of all women and $11.4 \%$ of all men $(9.3 \%$ of all respondents). During physical education classes, $3.6 \%$ of women and $2.1 \%$ of men from Łódź and $6.7 \%$ of men from Poznań do not take into account the real needs and interests of students, which may to a certain extent testify to their treatment (Table 6).

Table 6. The problem of "carrying out physical education classes, I try to take into account the real needs and interests of students"

\begin{tabular}{|c|c|c|c|c|c|c|c|}
\hline \multirow{2}{*}{$\begin{array}{l}\text { Type of } \\
\text { school }\end{array}$} & \multirow[b]{2}{*}{ Sex } & \multirow[b]{2}{*}{$N$} & \multicolumn{5}{|c|}{ Answers } \\
\hline & & & Definitely yes & Yes & $\begin{array}{c}\mathrm{I} \text { am } \\
\text { determined to }\end{array}$ & No & Definitely not \\
\hline \multirow{2}{*}{ SP } & $\mathrm{K}$ & 124 & 23.4 & 65.3 & 9.7 & 0 & 1.6 \\
\hline & $\mathrm{M}$ & 132 & 9.1 & 74.2 & 10.6 & 6.1 & 0 \\
\hline \multirow{2}{*}{$\mathrm{G}$} & $\mathrm{K}$ & 79 & 24.1 & 70.9 & 5.1 & 0 & 0 \\
\hline & $\mathrm{M}$ & 80 & 30.0 & 57.5 & 12.5 & 0 & 0 \\
\hline \multirow{2}{*}{ SPP } & $\mathrm{K}$ & 79 & 24.1 & 68.4 & 5.1 & 2.5 & 0 \\
\hline & $\mathrm{M}$ & 86 & 4.7 & 81.4 & 11.6 & 2.3 & 0 \\
\hline & & & \multicolumn{5}{|c|}{$\square^{2}=57.58 * *$} \\
\hline \multirow{2}{*}{ Together } & $\mathrm{K}$ & 282 & 23.8 & 67.7 & 7.1 & 0.7 & 0.7 \\
\hline & $\mathrm{M}$ & 298 & 13.4 & 71.8 & 11.4 & 3.4 & 0 \\
\hline & & & \multicolumn{5}{|c|}{$\square^{2}=18.655 * *$} \\
\hline Together & $M+M$ & 580 & 18.5 & 69.8 & 9.3 & 2.1 & 0.3 \\
\hline
\end{tabular}

The surveyed teachers were characterized by unusually high self-esteem of their professional work, which expressed the feeling of joy in contributing to the good health of students and the whole society (definitely yes - 26.9\% of all respondents, 31.6\% from Wroclaw, 27.5\% from Poznań, 22.4\% from Łódź, yes - 65\% of all respondents, 70.7\% from Łódź, 67.2\% from Poznań, 55.6\% from Wrocław). It was also found that 7.6\% of junior high school teachers, $7 \%$ from primary and $6.7 \%$ from post-primary schools did not specify their position in a given problem. A very small percentage of surveyed teachers from Poznań $(4.8 \%$ of women and $1.7 \%$ of men) do not feel joy that, through their work, it contributes to maintaining good health of students, and thus - the whole society (Table 7). 


\section{RADOSŁAW MUSZKIETA, MAREK NAPIERAŁA, MIROSŁAWA CIEŚLICKA, WALERY ZUKOW, ZHANETA KOZINA, SERGII IERMAKOV, MIROSŁAW GÓRNY}

Table 7. The problem of "the joy I feel that by working in my profession I contribute to the well being of students and society as a whole"

\begin{tabular}{|c|c|c|c|c|c|c|c|}
\hline \multirow[b]{2}{*}{$\begin{array}{l}\text { Type of } \\
\text { school }\end{array}$} & \multirow[b]{2}{*}{ Sex } & \multirow[b]{2}{*}{$N$} & \multicolumn{5}{|c|}{ Answers } \\
\hline & & & Definitely yes & Yes & $\begin{array}{c}\text { I am } \\
\text { determined to }\end{array}$ & No & Definitely not \\
\hline \multirow{2}{*}{ SP } & $\mathrm{K}$ & 124 & 30.7 & 61.3 & 4.8 & 3.2 & 0 \\
\hline & $\mathrm{M}$ & 132 & 24.2 & 66.7 & 9.1 & 0 & 0 \\
\hline \multirow{2}{*}{ G } & $\mathrm{K}$ & 79 & 36.7 & 63.3 & 0 & 0 & 0 \\
\hline & $\mathrm{M}$ & 80 & 32.5 & 50.0 & 15.0 & 2.5 & 0 \\
\hline \multirow{2}{*}{ SPP } & $\mathrm{K}$ & 79 & 24.1 & 68.4 & 7.6 & 0 & 0 \\
\hline & $\mathrm{M}$ & 86 & 14.0 & 80.2 & 5.8 & 0 & 0 \\
\hline & & & \multicolumn{5}{|c|}{$\square^{2}=42.548 * *$} \\
\hline \multirow{2}{*}{ Together } & $\mathrm{K}$ & 282 & 30.5 & 63.8 & 4.3 & 1.4 & 0 \\
\hline & $\mathrm{M}$ & 298 & 23.5 & 66.1 & 9.7 & 0.7 & 0 \\
\hline & & & \multicolumn{5}{|c|}{$\square^{2}=9.689 *$} \\
\hline Together & $M+M$ & 580 & 26.9 & 65.0 & 7.1 & 1.0 & 0 \\
\hline
\end{tabular}

The surveyed physical education teachers confirmed positive opinions about the search for new and creative methods, ways and means of didactic and educational activity in the lesson process. It was noted that 84.8\% (not - 55.6\%, definitely not - 29.2\%) teachers from Wrocław, 77.4\% (not - 57.8\%, definitely not - 19.6\%) from Poznań and 76.1\% (not - 52.7\%, definitely not - 23.4\%) from Łódź disagreed with the thesis that physical education can not change much. According to $4 \%$ of women and $4.6 \%$ of men from primary schools, $2.5 \%$ of women and $5 \%$ of men from middle schools, $2.5 \%$ of women and $7 \%$ of men from post-primary schools in school physical education can not change much. It was also found that $20.1 \%$ of all junior high school teachers, $18.2 \%$ employed in secondary school and $13.3 \%$ primary school showed a lack of decisiveness in expressing opinions on changes in physical education (Table 8).

Table 8. Problem "in physical education can be little change"

\begin{tabular}{|c|c|c|c|c|c|c|c|}
\hline \multirow{2}{*}{$\begin{array}{l}\text { Type of } \\
\text { school }\end{array}$} & \multirow[b]{2}{*}{ Sex } & \multirow[b]{2}{*}{$\mathrm{N}$} & \multicolumn{5}{|c|}{ Answers } \\
\hline & & & Definitely yes & Yes & $\begin{array}{c}\text { I am } \\
\text { determined to }\end{array}$ & No & Definitely not \\
\hline \multirow{2}{*}{ SP } & $\mathrm{K}$ & 124 & 0 & 4.0 & 16.1 & 55.7 & 24.2 \\
\hline & $\mathrm{M}$ & 132 & 0 & 4.6 & 10.6 & 62.1 & 22.7 \\
\hline \multirow{2}{*}{ G } & $\mathrm{K}$ & 79 & 2.5 & 0 & 20.3 & 48.1 & 29.1 \\
\hline & $\mathrm{M}$ & 80 & 0 & 5.0 & 20.0 & 52.5 & 22.5 \\
\hline \multirow{2}{*}{ SPP } & $\mathrm{K}$ & 79 & 0 & 2.5 & 20.3 & 45.6 & 31.7 \\
\hline & $\mathrm{M}$ & 86 & 0 & 7.0 & 16.3 & 62.8 & 14.0 \\
\hline & & & \multicolumn{5}{|c|}{$\square^{2}=34.044 *$} \\
\hline \multirow{2}{*}{ Together } & K & 282 & 0.7 & 2.5 & 18.4 & 50.7 & 27.7 \\
\hline & $\mathrm{M}$ & 298 & 0 & 5.4 & 14.8 & 59.7 & 20.1 \\
\hline & & & \multicolumn{5}{|c|}{$\square^{2}=11.92 *$} \\
\hline Together & $M+M$ & 580 & 0.3 & 4.0 & 16.6 & 55.3 & 23.8 \\
\hline
\end{tabular}

Analyzing the results of research included in table 9 , it was found that as many as $16.4 \%$ of teachers from Wrocław, $11.8 \%$ from Poznań and 8.8\% from Lodz do not conduct physical education lessons in accordance with the didactic and educational plan developed by them. The approach of the respondents to the mandatory development of work plans is highly reprehensible and puzzling. $18.1 \%$ of the surveyed men and $10.6 \%$ of women who do not know what plans they are working on are difficult to consider as positive. In this case, only $73.5 \%$ (definitely yes $-9.6 \%$ women and $7.4 \%$ men, yes $-67 \%$ women and $63.1 \%$ men) of the surveyed teachers work in accordance with the didactic and educational plans developed by them. Contrary to appearances, this does not indicate a positive attitude of professional physical education teachers (Table 9).

Table 9. Problem "On physical education classes work in accordance with a plan of their education and

upbringing"

\begin{tabular}{|c|c|c|c|c|c|c|c|}
\hline \multirow[b]{2}{*}{$\begin{array}{l}\text { Type of } \\
\text { school }\end{array}$} & \multirow[b]{2}{*}{ Sex } & \multirow[b]{2}{*}{$\mathrm{N}$} & \multicolumn{5}{|c|}{ Answers } \\
\hline & & & Definitely yes & Yes & $\begin{array}{c}\mathrm{I} \text { am } \\
\text { determined to }\end{array}$ & No & Definitely not \\
\hline \multirow{2}{*}{ SP } & $\mathrm{K}$ & 124 & 9.7 & 75.8 & 9.7 & 4.8 & 0 \\
\hline & $\mathrm{M}$ & 132 & 6.1 & 66.7 & 18.2 & 6.1 & 3.0 \\
\hline \multirow{2}{*}{$\mathrm{G}$} & K & 79 & 8.9 & 63.3 & 12.7 & 15.2 & 0 \\
\hline & $\mathrm{M}$ & 80 & 12.5 & 45.0 & 25.0 & 15.0 & 2.5 \\
\hline \multirow{2}{*}{ SPP } & $\mathrm{K}$ & 79 & 10.1 & 56.9 & 10.1 & 20.3 & 2.5 \\
\hline & $\mathrm{M}$ & 86 & 4.7 & 74.4 & 11.6 & 4.7 & 4.7 \\
\hline & & & \multicolumn{5}{|c|}{$\square^{2}=52,61 * *$} \\
\hline \multirow{2}{*}{ Together } & $\mathrm{K}$ & 282 & 9.6 & 67.0 & 10.6 & 12.1 & 0.7 \\
\hline & $\mathrm{M}$ & 298 & 7.4 & 63.1 & 18.1 & 8.1 & 3.4 \\
\hline & & & \multicolumn{5}{|c|}{$\square^{2}=13.997 * *$} \\
\hline Together & $M+M$ & 580 & 8.5 & 65.0 & 14.5 & 10.0 & 2.1 \\
\hline
\end{tabular}

96

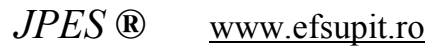




\section{Discussion}

Teacher of physical education in accordance with the Regulation of the Minister of Science and Higher Education of 17 January 2012 on the standards of education preparing to practice as a teacher (Journal of Laws, item 131) graduate of first-cycle studies (in kindergartens and primary schools) and II degree (middle and high schools).

The competences of a physical education teacher become a key component of modern education. Physical education may sometimes have irregularities that are warned by J. Bielski (2015). They may have a harmful character because they cause that education loses its sense and when there is no penetration of the influence of the subject acting with the student, then we are dealing with pseudo-behavior.

Factors that determine the teacher's work effectiveness and are closely related to him and the quality of the lesson. It consists of such elements as: organizational and ordering activities, the content of lessons, principles, methods and forms of conducting classes, and psycho-social coloring of the lesson (Wosik 1994).

During the physical education lesson clearly shows the teacher's attitude to the student, pro-social attitude of the teacher as and also the style of managing a class group. Good quality of lessons is a high level in terms of methodical implementation of classes. This requires the teacher to have the appropriate personality traits and the personality dimension affects the course and quality of the work performed.

Extrovert personality features, due to the appropriate number of characteristic and desirable personality traits, fit into the profession of a sports trainer or physical education teacher. Wosik (1994) states that the personality ideal of a physical education teacher would be an ambiwert, an intermediate individual combining the features of an extra and introvert.

Berczyński (2012) states that health education has been strongly emphasized in physical education. Since physical education teachers are the most prepared for it, it has become an additional challenge for them. The problem for the teacher may be the grade from physical education. Clear and clear wording of the criteria will make it easier to make decisions about the interim and annual evaluation. An important issue is the planning of the physical education teacher's work in the light of determining by the Ministry of Education the minimum number of teaching hours so as to maintain the continuity of the physical education process through all educational stages. Teachers, as noted by Berczyński, who teach at a higher stage, must know and know what skills and competences a student should have after completing previous levels of education.

Kozłowska and Ryszkowski (2012, p. 39) took care of communication skills. They carried out research aimed at self-assessment of communication competence of physical education teachers. The survey was conducted among 221 students - PE teachers, II degree students. The research results showed that teachers have communication skills at the levels: good: less than half of the respondents; average: $1 / 4$ subjects; very good: over $1 / 5$ of the respondents. It was confirmed that the majority of students have communication skills at good and medium level. At the highest level, the respondents have: the ability to show the taught exercises and sports (41.18\%); at a good level: knowledge and ability to use the proper terminology in teaching $(51.58 \%)$. The test results can be used to describe the teacher's work position and modify the competences of the physical education teacher.

Krawański (2009) sees deficiencies in physical education from the perspective of the body and health, which may cause the need to train teachers and students in this area. This situation requires that the classes should include a broader perspective of the social and psychological determinants of the body and health: knowledge about the principles of health promotion, social determinants of behavior. The student should learn in the lesson why he is doing boring exercises and what he will benefit from in everyday life. The author states that in order to pursue such a perspective of physical education, the teacher's current pedagogical competence must undergo a fundamental reorientation in the direction enabling the non-objective impact on the learner's personality (Krawański 2009, p. 91).

The contemporary world is constantly changing, and the teachers of the Polish school should change with it if they are to be promoters of changes, specialists in the field of education methods, experts in the subject of teaching, people sensitive to the needs of their pupils. The physical education teacher with his attitude has a very significant impact on participation in physical activity, especially of young generations.

Kumala, Krzak (2013) conducted research on 129 students from selected universities in Wrocław regarding the image of a physical education teacher. The aim of the research was to get to know the opinions of students of selected universities regarding

Kumala, Krzak (2013) conducted research on 129 students from selected universities in Wrocław regarding the image of a physical education teacher. The aim of the research was to get to know the opinions of students of selected universities regarding the characteristics of a physical education teacher to the attitudes declared by them towards physical activity.

The results showed that teachers do not take into account that their inappropriate attitude presented in physical education lessons can significantly affect the relationship to the lifelong physical activity of their charges. It should be remembered that a teacher tailored to the needs of modern society should strive to acquire new knowledge and skills, as well as forecasted for the future Kumula, Krzak (2013, pp. 36-41). 
The competences of physical education teachers to implement health education were taken up by Czechowski and Żukowska (2010, pp. 395-399). In their work, they characterized the subject competences (knowledge and didactic-organizing skills) and pedagogical skills (moral, praxeological, communication, creative and IT competences). Physical education teachers, which are necessary for the effective implementation of the health education program.

They noted that the role and significance of pedagogical competences, which in this respect determine the effectiveness of health education, are less frequently noticed.

Wiesner (2005) introduced the topic of didactic communication to physical education lessons. The diversity of work in various conditions of a physical education teacher results from the specificity of places for conducting physical education classes - a sports hall, a school playground, a swimming pool, an ice rink, and a natural environment.

In an emergency, the teacher may display authoritarian features that are often associated with autocratic leadership styles. The teacher's authoritarianism usually influences the course of didactic communication with students. Positive correlations were recorded between the level of authoritarian personality of teachers and verbal activities. Attitudes and competences of a physical education teacher influence the effects and quality of work, and above all, the achievements of each student. The teacher, immediately after the parents, is the main figure acting on the multidirectional and harmonious development of the student, on his attitudes, behaviors and attitudes.

\section{Conclusions}

To summarize the above considerations, the following generalizations can be made:

The vast majority of the surveyed teachers positively referred to the acquisition of further degrees of professional advancement, improvement and vocational training and reform of the education system in Poland.

The professional attitudes of physical education teachers can be considered satisfactory, and thus - giving an opportunity for a better quality of education and upbringing of children and youth. However, there is a certain dissonance between the declared attitudes and the real conduct of many teachers.

The teacher according to Żukowska (1993) "is a profession and calling, it is innate and learned abilities, it is an appropriate set of personality and temperamental traits, it is the ability to sacrifice for the sake of others, it is love for children".

\section{Declarations}

\section{Ethics approval and consent to participate}

The research related to human use complied with all the relevant national regulations, institutional policies, and was in accordance with the tenets of the Helsinki Declaration. The study protocol was approved by the Ethical Committee of Poznań University of Physical Education, Poznań, Poland.

During realization of tests, all participants provided informed consent and used all measures for maintaining anonymity of participants.

Consent to publish - Not applicable

Competing interests -The authors declare that they have no competing interests.

Funding -No funding

Authors' contributions

$\mathrm{RM}, \mathrm{MN}, \mathrm{WZ}$ participated in the design of this study.RM performed the statistical analyses. RM, MN, WZ, MC, SI, ZK, MG drafted the manuscript. MC, SI, ZK were involved in data collection and/or made important intellectual contributions to the interpretation of data and the writing of paper. All authors RM, MN, MC, WZ, SI, ZK, MG critically revised and approved the final version.

Acknowledgements - Not applicable

\section{References}

Bielski J. (2015). Błędy w procesie wychowania fizycznego (Przeciwieństwa wychowania). Lider, N 10 /298/ s. 33-41

Berczyński M. (2012). Wychowanie fizyczne w szkole. Poradnik dla nauczyciela, Ośrodek Rozwoju Edukacji, Warszawa, s.4-5

Brophy J., Research on Teaching and Teacher Education: The Interface. [W:] P. Grimmett (red.), Research in Teacher Education: Current Problems and Future Prospects in Canada. University of British Columbia 1984.

Czechowski M., Żukowska Z. (2010). Kompetencje nauczycieli wychowania fizycznego do realizacji edukacji zdrowotnej, ROCZN. PZH 61, Nr 4, 395 - 399

Czabański B., O duszy nauczycielstwa wychowania fizycznego. „Życie Akademickie”, 1997, nr 2.

Dindorf M., Nauczyciel. [W:] B. Czabański. Elementy dydaktyki ogólnej. Wrocław 1995. 
Hasan, Melki, Mohamed, S. Bouzid, Aymen, Haweni, Mourad, Fadhloun, Meher, Mrayeh, \& Nizar, Souissi (2017). Formative Assessment: Exploring Tunisian Cooperative Teachers Practices in Physical Education. Pedagogics, Psychology, Medical-Biological Problems of Physical Training and Sports, 21(5), 227-235. doi:10.15561/18189172.2017.0505

Konarzewski K. (red.), Sztuka nauczania. Szkoła. Warszawa 1998; idem, Sztuka nauczania. Czynności nauczyciela. Warszawa 1998.

Kozłowska D., Ryszkowski W. (2012). Kompetencje komunikacyjne nauczycieli wychowania fizycznego, Roczniki Naukowe Wyższej Szkoły Wychowania Fizycznego i Turystyki w Białymstoku, s.39-46

Krawański A. (2009). Wychowanie fizyczne w nowym systemie kształcenia ogólnego MEN - kilka refleksji, Zdrowie - Kultura Zdrowotna - Edukacja, AWFiS, Gdańsku, t. III s. 91-93,

Kumala R., Krzak M. (2013). Retrospektywny obraz nauczyciela wychowania fizycznego a postawa studenta wobec aktywności fizycznej, Rozprawy Naukowe Akademii Wychowania Fizycznego we Wrocławiu, Nr 40, 36-41

Leifa, A.V., \& Zheleznyak, Y.D. (2017). Influence of physical activity on students' life quality. Physical Education of Students, 21(5), 244-248. doi:10.15561/20755279.2017.0507

Nowak, Agata, Romanowska-Tolloczko, Anna, \& Knysak, Monika (2016). Primary teachers knowledge about psychomotor disturbances occuring in children. Pedagogics, Psychology, MedicalBiological Problems of Physical Training and Sports, 20(1), 52-57. doi:10.15561/18189172.2016.0108

Özkara, Abdullah Bora, Kalkavan, Arslan, Alemdağ, Serdar, Alemdağ, Ceyhun, \& Çavdar, Selma (2017). The role of physical activity in pre-service teachers' subjective vitality. Physical Education of Students, 21(3), 134-139. doi:10.15561/20755279.2017.0306

Pearson A., Nauczyciel. Teoria i praktyka w kształceniu nauczycieli. Warszawa 1994.

Wosik G. (1994). Jakość lekcji wychowania fizycznego a wymiar osobowości nauczyciela Prace Naukowe. Pedagogika, Nr 5, 235-240

Wiesner W. (2005). Komunikacja dydaktyczna na lekcjach wychowania fizycznego a poziom autorytaryzmu nauczycieli, AWF, Wrocław 2005 ISSN 0239-6009 ISBN 83-89156-34-2

Żukowska Z., Nauczyciel: człowiek - pedagog - specjalista. „Wychowanie Fizyczne i Zdrowotne”, 1993, nr 4, s.110 